IRA-International Journal of Management \& Social Sciences

ISSN 2455-2267; Vol.05, Issue 01 (2016)

Pg. no. $175-186$

Institute of Research Advances

http://research-advances.org/index.php/RAJMSS

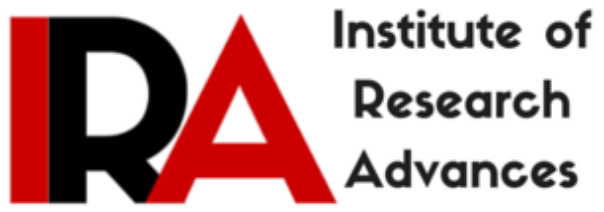

\title{
Analysis of Employment of Women Salaries in Family and its Impact on the Status of Family of Kota City
}

\author{
${ }^{1}$ CMA Dr. Meenu Maheshwari, ${ }^{2}$ Priya Sodani. \\ ${ }^{1}$ Assisstant Professor \& Former Head, Department of Commerce \& \\ Management,University of Kota, Kota (Raj.), India. \\ ${ }^{2}$ Research Scholar, Department of Commerce \& Management, University of Kota, \\ Kota(Raj.), India.
}

Type of Review: Peer Reviewed.

DOI: http://dx.doi.org/10.21013/jmss.v5.n1.p17

\section{How to cite this paper:}

Maheshwari, M., \& Sodani, P. (2016). Analysis of Employment of Women Salaries in Family and its Impact on the Status of Family of Kota City. IRA-International Journal of Management \& Social Sciences (ISSN 2455-2267), 5(1), 175-186. doi:http://dx.doi.org/10.21013/jmss.v5.n1.p17

(C) Institute of Research Advances

\section{(c) EY-NC}

This work is licensed under a Creative Commons Attribution-Non Commercial 4.0 International License subject to proper citation to the publication source of the work.

Disclaimer: The scholarly papers as reviewed and published by the Institute of Research Advances (IRA) are the views and opinions of their respective authors and are not the views or opinions of the IRA. The IRA disclaims of any harm or loss caused due to the published content to any party. 


\begin{abstract}
This paper seeks to analyse the relationship between the women's opinion for the extent of employment of their income in different heads of family and its overall effect on family status of Kota city. This analysis of women participants' opinion of Kota city for the factors of family which are nourished by their income are Financial Position and Status, Societal Status and Position, Living Standard and Statue, Education of Children, Family and Personal Health Security, Quality of life and Risk taking capabilities. Distribution of women participants' opinion for application of their salaries in different expenditure heads of family are: in constructing home, in buying cars and automobiles, in education fees, in Insurance / Family Security, in Recreation and Leisure time, in Saving and Deposits / Investments, in Routine Expenses, in Medical and Health Issues, and in Paying Taxes. Their opinion might be influenced by the age group, educational qualification and current sector of their job. It has been an empirical study involving a questionnaire collected from 450 working women respondents working in Kota city, Rajasthan. A deep analysis of the findings will be discussed in this paper.
\end{abstract}

Keywords: Social status, Financial Position, Risk taking capabilities.

\title{
Introduction
}

Rural women have continually been working in the fields and farms from time immemorial. They were working and they now continue to work. Work in the lives of majority of women is not a matter of selfequity. Changing economic roles and duties of women, particularly among the poor, make employment/work a matter of economic survival. Male unemployment or male low earnings resulting due to wage labour and high rates of urbanization have also meant an increase in the number of married women workers. Low male wages frequently impose double responsibilities on married women who need to substitute the family income through additional home production and work out-side the home. Women's contribution to household income provides the means to meet basic survival needs such as food, clothing and shelter. Ultimately, women's contribution makes possible improvements in the health and nutritional status of household members.

The great change, however took place when the machines were introduced. Women were employed in factories, mines and plantations. There was spectacular increase in the employment of middle class women who were working in secretarial or administrative capacities. More women are now working as stenographers, clerks, telephone operators and receptionists. In the educational field also teachers at primary and secondary levels has been women. Women's participation in all spheres highlights their changing role and the emerging pattern points towards equality of sex.

An individual's earning is employed under several heads in family; same may also be observed for the women participants salaries as well. It is crucial to examine the heads where salaries of majority of women are employed with in the family.

\section{Objective}

The main purpose of this study is to analyse the relationship between the women's opinion for the extent of employment of their income in different heads of family and its overall effect on family status of Kota city.

\section{Hypothesis}

To examine the relationship between the women participants' opinion for the income used in different heads of family and its overall impact on the different factors following hypothesis have been formulated. $\mathbf{H}_{\mathbf{0 1 3}}$ : Application of working women income in different heads of family does not nourish their family statue. 
$\mathbf{H}_{\mathbf{a} 13}$ : Application of working women income in different heads of family nourishes their family statue. Collection of Data

The data have been collected from both primary and secondary sources. The primary data have been collected from women who are engaged in different economic activities such as Self owned business, government jobs, semi-government jobs and private jobs, with the help of Questionnaire. The questionnaire has been administered to identify major heads among 9 listed head where salary of women is being majorly employed with in the family and has been administered to examine the women participants' opinion about the impact of their salaries employment on different dimensions of family. Sample of 450 women of Kota city has been taken in the study. They have been selected through stratified random sampling technique for data collection. In our study economic activity has been defined as employment for wages, self-employment, own account worker, piece worker and work in household business/enterprise, micro-enterprise which results into income of woman in the form of cash or kind. This study is an empirical one, based on survey method. Secondary data has been collected through various sources such as websites, journals, articles, and books.

\section{Demographic profile of respondents}

This section majorly examines personal information of the women participants like participants name, age, marital status, monthly income, family type, Qualification, number of children, preference to do job, current job status and their opinion about the sector which is good for women with respect to job. Some of the major conclusions are: Out of 450 women respondents $221(49.1 \%)$ was of 20-35 years age group of women, $48(10.7 \%)$ was observed from below 20 years age group of women, $105(23.3 \%)$ of participated women were of 36-50 years age group and $76(16.9 \%)$ of participated women of 51 years and above age group. Out of 450 women participants $293(65.1 \%)$ of women were married, $111(24.7 \%)$ of women were unmarried, $34(7.6 \%)$ of women were divorcee and $12(2.7 \%)$ of women were widow. 143 (31.8\%) women participants were earning in between ₹10000 - 30000 per month, $124(27.6 \%)$ women were earning in between ₹ 30000 - 50000 per month, 121 (26.9\%) women participants were earning lesser than and equal to ₹ 10000 per month and remaining $62(13.8 \%)$ women were earning more than and equal to ₹ 50000 per month. $226(50.2 \%)$ of women participants were living in nuclear family, 183 $(40.7 \%)$ of women were living in joint families and remaining $41(9.1 \%)$ of women participant of Kota city are living single. $80(17.8 \%)$ women were undergraduate, $114(25.3 \%)$ women were graduate, 123 (27.3\%) women were post graduate, 67 (14.9\%) women were professionally qualified and remaining 66 (14.7\%) women were having several other academic qualifications. 161 (35.8\%) women were having more than two children, $119(26.4 \%)$ women were having only one children and $24(5.3 \%)$ women were having more than two children and 146 (32.4\%) women were not having any child. 150 (33.3\%) women were of public sector, $150(33.3 \%)$ women were of private sector, $100(22.2 \%)$ women were having their own business, $50(11.1 \%)$ women were of semi government sector. $183(40.7 \%)$ women preferred public sector for women, 138 (30.7\%) of participated women preferred own business / self-employment for women, $69(15.3 \%)$ of participated women preferred private sector for women and remaining $60(13.3 \%)$ of participated women opinion as preferred sector was for private sector. Highest level of agreement was given to retail sector as a good sector for women and second highest preference was given to call centre jobs.

\section{Data Analysis}

To examine the major heads where salaries of women is employed with in the family frequency analysis and One Sample T-Test has been applied to examine the significance of difference between the proposed constant of the population mean and calculated sample mean one sample T-test has been performed. Positive t score and significance will present the head as major head where salaries are employed with in the family. The proposed constant of the population mean is 1.64 which is an average value of responses observed. 
Table 1: Frequency Distribution of women participants' opinion for application of their salaries in different expenditure heads of family

\begin{tabular}{|c|c|c|c|c|c|}
\hline \multicolumn{6}{|c|}{ In Constructing Home } \\
\hline & & Frequency & Percent & Valid Percent & Cumulative Percent \\
\hline \multirow{3}{*}{ Valid } & No & 232 & 51.6 & 51.6 & 51.6 \\
\hline & Yes & 218 & 48.4 & 48.4 & 100.0 \\
\hline & Total & 450 & 100.0 & 100.0 & \\
\hline \multicolumn{6}{|c|}{ In buying Car / automobiles } \\
\hline & & Frequency & Percent & Valid Percent & Cumulative Percent \\
\hline \multirow{3}{*}{ Valid } & No & 208 & 46.2 & 46.2 & 46.2 \\
\hline & Yes & 242 & 53.8 & 53.8 & 100.0 \\
\hline & Total & 450 & 100.0 & 100.0 & \\
\hline \multicolumn{6}{|c|}{ In Education / Fees } \\
\hline & & Frequency & Percent & Valid Percent & Cumulative Percent \\
\hline \multirow{3}{*}{ Valid } & No & 124 & 27.6 & 27.6 & 27.6 \\
\hline & Yes & 326 & 72.4 & 72.4 & 100.0 \\
\hline & Total & 450 & 100.0 & 100.0 & \\
\hline \multicolumn{6}{|c|}{ In Insurance / Family Security } \\
\hline & & Frequency & Percent & Valid Percent & Cumulative Percent \\
\hline \multirow{3}{*}{ Valid } & No & 177 & 39.3 & 39.3 & 39.3 \\
\hline & Yes & 273 & 60.7 & 60.7 & 100.0 \\
\hline & Total & 450 & 100.0 & 100.0 & \\
\hline \multicolumn{6}{|c|}{ In Recreation and Leisure time } \\
\hline & & Frequency & Percent & Valid Percent & Cumulative Percent \\
\hline \multirow{3}{*}{ Valid } & No & 154 & 34.2 & 34.2 & 34.2 \\
\hline & Yes & 296 & 65.8 & 65.8 & 100.0 \\
\hline & Total & 450 & 100.0 & 100.0 & \\
\hline \multicolumn{6}{|c|}{ In Saving and Deposits / Investments } \\
\hline & & Frequency & Percent & Valid Percent & Cumulative Percent \\
\hline \multirow{3}{*}{ Valid } & No & 160 & 35.6 & 35.6 & 35.6 \\
\hline & Yes & 290 & 64.4 & 64.4 & 100.0 \\
\hline & Total & 450 & 100.0 & 100.0 & \\
\hline \multicolumn{6}{|c|}{ In Routine Expenses } \\
\hline & & Frequency & Percent & Valid Percent & Cumulative Percent \\
\hline \multirow{3}{*}{ Valid } & No & 109 & 24.2 & 24.2 & 24.2 \\
\hline & Yes & 341 & 75.8 & 75.8 & 100.0 \\
\hline & Total & 450 & 100.0 & 100.0 & \\
\hline \multicolumn{6}{|c|}{ In Medical and Health Issues } \\
\hline & & Frequency & Percent & Valid Percent & Cumulative Percent \\
\hline \multirow{3}{*}{ Valid } & No & 136 & 30.2 & 30.2 & 30.2 \\
\hline & Yes & 314 & 69.8 & 69.8 & 100.0 \\
\hline & Total & 450 & 100.0 & 100.0 & \\
\hline
\end{tabular}




\begin{tabular}{|l|l|l|l|l|l|}
\hline \multicolumn{2}{|l|}{ In Paying Taxes } \\
\hline \multicolumn{2}{|l|}{} & Frequency & Percent & Valid Percent & Cumulative Percent \\
\hline \multirow{3}{*}{ Valid } & No & 122 & 27.1 & 27.1 & 27.1 \\
\cline { 2 - 6 } & Yes & 328 & 72.9 & 72.9 & 100.0 \\
\cline { 2 - 6 } & Total & 450 & 100.0 & 100.0 & \\
\hline
\end{tabular}

\section{Source: Field Survey Year 2015}

Statistical presentation of frequency distribution of women opinion for application of their salaries in nine heads has been shown in Table 1. It can be observed from the table that 218 (48.4\%) women agreed that their salaries have been used in constructing home, $242(53.8 \%)$ women agreed that their salaries has been used in buying automobile, $326(72.4 \%)$ women agreed that their salaries has been used in education / fees, $273(60.7 \%)$ women agreed that their salaries has been used in insurance and family security, 296 $(65.8 \%)$ women agreed that their salaries has been used in recreation and leisure time, $290(64.4 \%)$ women agreed that their salaries has been used in saving deposits and investments, 341 (75.8\%) women agreed that their salaries has been used in routine expenses of family, $314(69.8 \%)$ women agreed that their salaries has been used in medical and health issues and 328 (72.9\%) women agreed that their salaries has been used in paying taxes.

Thus highest percentage $341(75.8 \%)$ women agreed that their salaries has been applied in daily routine expenses of family and least application of salaries has been performed in constructing home for this only $218(48.4 \%)$ women give their positive consent.

Table 2: One sample statistics of women participants' opinion for application of their salaries in different expenditure heads of family

\begin{tabular}{|l|l|l|l|l|}
\hline One-Sample Statistics & $\mathrm{N}$ & Mean & Std. Deviation & Std. Error Mean \\
\hline In Constructing Home & 450 & 1.4844 & .50031 & .02359 \\
\hline In buying Car / automobiles & 450 & 1.5378 & .49913 & .02353 \\
\hline In Education / Fees & 450 & 1.7244 & .44729 & .02109 \\
\hline In Insurance / Family Security & 450 & 1.6067 & .48903 & .02305 \\
\hline In Recreation and Leisure time & 450 & 1.6578 & .47498 & .02239 \\
\hline $\begin{array}{l}\text { In Saving and Deposits } \\
\text { Investments }\end{array}$ & 450 & 1.6444 & .47921 & .02259 \\
\hline In Routine Expenses & 450 & 1.7578 & .42890 & .02022 \\
\hline In Medical and Health Issues & 450 & 1.6978 & .45973 & .02167 \\
\hline In Paying Taxes & 450 & 1.7289 & .44503 & .02098 \\
\hline
\end{tabular}

\section{Source: Field Survey Year 2015}

Table 2 presents mean score values with the related standard deviation for the women participants opinion for application of their salaries in different heads of family expenditure. Observed values for application of salaries in different heads are for "In constructing home" is $1.48 \pm 0.50$, for "in busying car / automobiles" is $1.53 \pm 0.49$, for "In education / fees" is $1.72 \pm 0.44$, for "In insurance / family security" is 
$1.60 \pm 0.48$, for "In recreation and leisure time" is $1.65 \pm 0.47$, for "In saving deposits / Investments" is $1.64 \pm 0.47$, for "In Routine expenses" is $1.75 \pm 0.42$, for "In medical and health issues" is $1.69 \pm 0.45$ and for "In paying taxes" is $1.72 \pm 0.44$. Thus it has been concluded that variability in the responses could observe.

Highest mean score has been observed for "In Routine expenses" which showed that salaries of women majorly applied in this head and least mean score has been observed for "In constructing house" which shows that salaries of women applied in this head in least cases in comparison to other heads.

Table 3: One Sample test of women participants' opinion for application of their salaries in different expenditure heads of family

\begin{tabular}{|c|c|c|c|c|c|c|}
\hline \multicolumn{7}{|l|}{ One-Sample Test } \\
\hline & \multicolumn{6}{|c|}{ Test Value $=1.64$} \\
\hline & \multirow[t]{2}{*}{$\mathrm{T}$} & \multirow[t]{2}{*}{ Df } & \multirow[t]{2}{*}{$\begin{array}{l}\text { Sig. } \\
\text { tailed })\end{array}$} & \multirow[t]{2}{*}{$\begin{array}{l}\text { Mean } \\
\text { Difference }\end{array}$} & \multicolumn{2}{|c|}{$\begin{array}{ll}95 \% & \text { Confidence } \\
\text { Interval of the } \\
\text { Difference }\end{array}$} \\
\hline & & & & & Lower & Upper \\
\hline In Constructing Home & -6.596 & 449 & .000 & -.15556 & -.2019 & -.1092 \\
\hline In buying Car / automobiles & -4.345 & 449 & .000 & -.10222 & -.1485 & -.0560 \\
\hline In Education / Fees & 4.005 & 449 & .000 & .08444 & .0430 & .1259 \\
\hline In Insurance / Family Security & -1.446 & 449 & .149 & -.03333 & -.0786 & .0120 \\
\hline In Recreation and Leisure time & .794 & 449 & .428 & .01778 & -.0262 & .0618 \\
\hline $\begin{array}{lr}\text { In Saving and Deposits } \\
\text { Investments }\end{array}$ & .197 & 449 & .844 & .00444 & -.0400 & .0488 \\
\hline In Routine Expenses & 5.825 & 449 & .000 & .11778 & .0780 & .1575 \\
\hline In Medical and Health Issues & 2.666 & 449 & .008 & .05778 & .0152 & .1004 \\
\hline In Paying Taxes & 4.237 & 449 & .000 & .08889 & .0477 & .1301 \\
\hline
\end{tabular}

\section{Source: Field Survey Year 2015}

Observations derived from the statistical values of women participants' opinion for application of their salaries in different expenditure heads of family presented in one sample T-test Table 3 are as follows:

1. Women participants opinion for their income contribution in "constructive home" shows significance (Sig. $=.000$ ) with the negative $t$ value -6.596 which show the significant statistical difference between the sample estimated populations mean and the comparison population mean. But due to negative $t$ value it presents that this is not the major head where women salaries are applied in families.

2. Women participants opinion for their income contribution in "buying cars or automobiles" shows significance (Sig. $=.000$ ) with the negative $\mathrm{t}$ value -6.596 which show the significant statistical difference between the sample estimated populations mean and the comparison population mean. But due to negative $t$ value it presents that this is not the major head where women salaries are applied in families.

3. Women participants opinion for their income contribution in "education and fees" shows significance $($ Sig. $=.000)$ with the positive $\mathrm{t}$ value 4.005 which show the significant statistical difference between the sample estimated populations mean and the comparison population mean. But due to negative $t$ value it presents that education and fees is the major head where women salaries are applied in families.

4. Women participants opinion for their income contribution in "insurance and family security" shows insignificance $(\mathrm{Sig} .=.149$ ) with the negative $t$ value -1.446 which show that there is no statistical 
difference between the sample estimated populations mean and the comparison population mean. Thus insurance and family security is not the major head where women salaries are applied in families.

5. Women participants opinion for their income contribution in "recreation and leisure time" shows insignificance $(\mathrm{Sig} .=.428$ ) with the positive $\mathrm{t}$ value .794 which show that there is no statistical difference between the sample estimated populations mean and the comparison population mean. Thus recreation and leisure time is not the major head where women salaries are applied in families.

6. Women participants opinion for their income contribution in "saving deposits and investments" shows insignificance $($ Sig. $=.844$ ) with the positive $\mathrm{t}$ value .197 which show that there is no statistical difference between the sample estimated populations mean and the comparison population mean. Thus saving deposits and investments is not the major head where women salaries are applied in families.

7. Women participants opinion for their income contribution in "routine expenses" shows significance (Sig. $=.000)$ with the positive $t$ value 5.825 which show the significant statistical difference between the sample estimated populations mean and the comparison population mean. Thus routine expenses are the major head where women salaries are applied in families.

8. Women participants opinion for their income contribution in "medical and health issues" shows significance $($ Sig. $=.008$ ) with the positive $t$ value 2.666 which show the significant statistical difference between the sample estimated populations mean and the comparison population mean. Thus medical and health issues are the major head where women salaries are applied in families.

9. Women participants opinion for their income contribution in "paying taxes" shows significance (Sig. $=.000$ ) with the positive $\mathrm{t}$ value 4.237 which show the significant statistical difference between the sample estimated populations mean and the comparison population mean. Thus paying taxes is the major head where women salaries are applied in families.

Table 4: Frequency Distribution of women participants' opinion for factors of family Nourished by Income of Job or Business

Financial Position and Status

\begin{tabular}{|l|l|l|l|l|l|}
\hline \multicolumn{2}{|c|}{} & Frequency & Percent & Valid Percent & Cumulative Percent \\
\hline \multirow{3}{*}{ Valid } & No & 172 & 38.2 & 38.2 & 38.2 \\
\cline { 2 - 6 } & Yes & 278 & 61.8 & 61.8 & 100.0 \\
\cline { 2 - 6 } & Total & 450 & 100.0 & 100.0 & \\
\hline \multirow{2}{*}{ Socien }
\end{tabular}

Societal Status and Position

\begin{tabular}{|l|l|l|l|l|l|}
\hline \multicolumn{2}{|c|}{} & Frequency & Percent & Valid Percent & Cumulative Percent \\
\hline \multirow{3}{*}{ Valid } & No & 174 & 38.7 & 38.7 & 38.7 \\
\cline { 2 - 6 } & Yes & 276 & 61.3 & 61.3 & 100.0 \\
\cline { 2 - 6 } & Total & 450 & 100.0 & 100.0 & \\
\hline
\end{tabular}

Living Standard and Statue

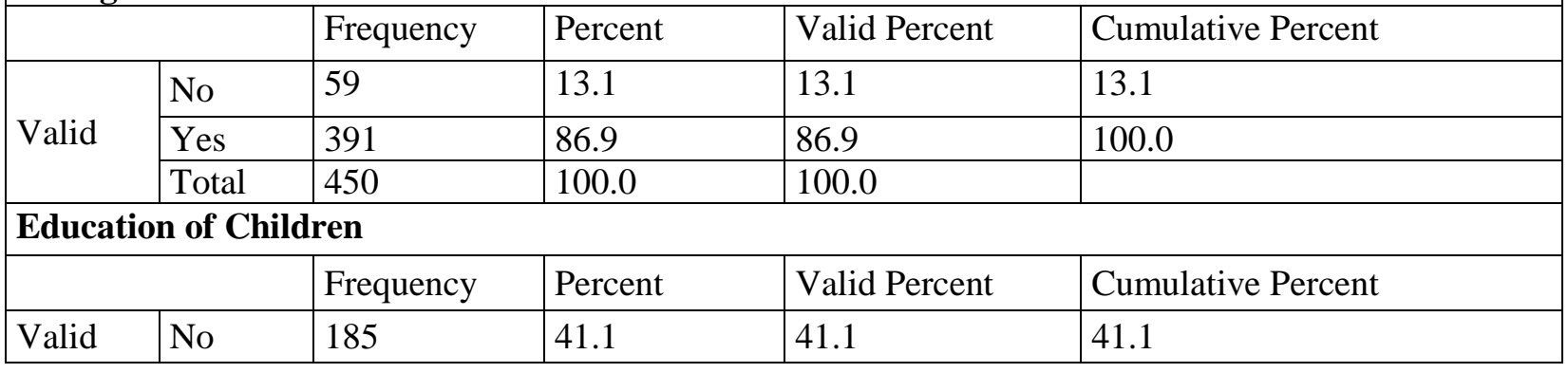




\begin{tabular}{|c|c|c|c|c|c|}
\hline & Yes & 265 & 58.9 & 58.9 & 100.0 \\
\hline & Total & 450 & 100.0 & 100.0 & \\
\hline Famil & nd Per & al Health Sc & ity & & \\
\hline & & Frequency & Percent & Valid Percent & Cumulative Percent \\
\hline & No & 195 & 43.3 & 43.3 & 43.3 \\
\hline Valid & Yes & 255 & 56.7 & 56.7 & 100.0 \\
\hline & Total & 450 & 100.0 & 100.0 & \\
\hline Socia & volven & & & & \\
\hline & & Frequency & Percent & Valid Percent & Cumulative Percent \\
\hline & No & 197 & 43.8 & 43.8 & 43.8 \\
\hline Valid & Yes & 253 & 56.2 & 56.2 & 100.0 \\
\hline & Total & 450 & 100.0 & 100.0 & \\
\hline Quali & f life & & & & \\
\hline & & Frequency & Percent & Valid Percent & Cumulative Percent \\
\hline & No & 150 & 33.3 & 33.3 & 33.3 \\
\hline Valid & Yes & 300 & 66.7 & 66.7 & 100.0 \\
\hline & Total & 450 & 100.0 & 100.0 & \\
\hline Risk t & ng cap & ities & & & \\
\hline & & Frequency & Percent & Valid Percent & Cumulative Percent \\
\hline & No & 132 & 29.3 & 29.3 & 29.3 \\
\hline Valid & Yes & 318 & 70.7 & 70.7 & 100.0 \\
\hline & Total & 450 & 100.0 & 100.0 & \\
\hline
\end{tabular}

\section{Source: Field Survey Year 2015}

Statistical presentation of frequency distribution of women opinion for impact of their income on family under eight heads has been shown in Table 4. It has been found from the table that $278(61.8 \%)$ women agreed that their salaries are nourishing financial position and statue of family, $276(61.3 \%)$ women agreed that their salaries are nourishing societal status and position of family, 391 (86.9\%) women agreed that their salaries are nourishing living standard and statue of family, $265(58.9 \%)$ women agreed that their salaries are nourishing education status of children of family, 255 (56.7\%) women agreed that their salaries are nourishing family and personal health, $253(56.2 \%)$ women agreed that their salaries are nourishing social involvement of family, 300 (66.7\%) women agreed that their salaries are nourishing quality of life of family and $318(70.7 \%)$ women agreed that their salaries are nourishing risk taking capabilities of family.

Thus societal status and position of family is affected the most by the income of women and social involvement is least affected head by the income of women.

To examine the major factors of family which has been nourished by the income of women, One Sample T-Test have been applied to examine the significance of difference between the proposed constant of the population mean and calculated sample mean one sample T-test has been performed. Positive $t$ score and significance will present the factors as major factor which is positively affected by the income of women. The proposed constant of the population mean is 1.52 which is an average value of responses observed. 
Table 5: One Sample Statistics of women participants' opinion for factors of family Nourished by Income of Job or Business

\begin{tabular}{|l|l|l|l|l|}
\hline One-Sample Statistics & $\mathrm{N}$ & Mean & Std. Deviation & Std. Error Mean \\
\hline & 450 & 1.6178 & .48647 & .02293 \\
\hline Financial Position and Status & 450 & 1.6133 & .48753 & .02298 \\
\hline Societal Status and Position & 450 & 1.8689 & .33790 & .01593 \\
\hline Living Standard and Statue & 450 & 1.5889 & .49258 & .02322 \\
\hline Education of Children & 450 & 1.5667 & .49609 & .02339 \\
\hline Family and Personal Health Security & 450 & 1.5622 & .49667 & .02341 \\
\hline Social Involvement & 450 & 1.6667 & .47193 & .02225 \\
\hline Quality of life & 450 & 1.7067 & .45580 & .02149 \\
\hline Risk taking capabilities & & & &
\end{tabular}

\section{Source: Field Survey Year 2015}

Table 5 presents mean score values with the related standard deviation for the women participants opinion for family factors nourished by the income of women. Observed values for nourished factors of family by the income of women are for "financial position and status" is $1.61 \pm 0.48$, for "Societal status and position" is $1.61 \pm 0.48$, for "Living standard and statue" is $1.86 \pm 0.34$, for "Education of children" is $1.58 \pm 0.49$, for "family and personal health security" is $1.56 \pm 0.49$, for "Social involvement" is $1.56 \pm$ 0.49 , for "Quality of work life" is $1.66 \pm 0.47$ and for "Risk taking capabilities" is $1.70 \pm 0.45$. Thus it could conclude that variability in the responses could observe.

Highest mean score has been observed for "Living standard and statue" which shows that salaries of women majorly nourishes this factor of families and least mean score has been observed for "Social Involvement" which shows that salaries of women nourishes this factor of families at least level.

Table 6: One Sample T-Test of women participants' opinion for factors of family Nourished by Income of Job or Business

\begin{tabular}{|c|c|c|c|c|c|c|}
\hline \multicolumn{7}{|l|}{ One-Sample Test } \\
\hline & \multicolumn{6}{|c|}{ Test Value $=1.52$} \\
\hline & \multirow[t]{2}{*}{$\mathrm{T}$} & \multirow[t]{2}{*}{ Df } & \multirow[t]{2}{*}{\begin{tabular}{|l|} 
Sig. \\
tailed $)$
\end{tabular}} & \multirow[t]{2}{*}{$\begin{array}{l}\text { Mean } \\
\text { Difference }\end{array}$} & \multicolumn{2}{|c|}{$\begin{array}{ll}95 \% & \text { Confidence } \\
\text { Interval of the } \\
\text { Difference }\end{array}$} \\
\hline & & & & & Lower & Upper \\
\hline Financial Position and Status & 4.264 & 449 & .000 & .09778 & .0527 & .1428 \\
\hline Societal Status and Position & 4.061 & 449 & .000 & .09333 & .0482 & .1385 \\
\hline Living Standard and Statue & 21.903 & 449 & .000 & .34889 & .3176 & .3802 \\
\hline Education of Children & 2.967 & 449 & .003 & .06889 & .0233 & .1145 \\
\hline $\begin{array}{l}\text { Family and Personal Health } \\
\text { Security }\end{array}$ & 1.996 & 449 & .047 & .04667 & .0007 & .0926 \\
\hline Social Involvement & 1.803 & 449 & .072 & .04222 & -.0038 & .0882 \\
\hline Quality of life & 6.593 & 449 & .000 & .14667 & .1029 & .1904 \\
\hline Risk taking capabilities & 8.688 & 449 & .000 & .18667 & .1444 & .2289 \\
\hline
\end{tabular}

\section{Source: Field Survey Year 2015}


Observations derived from the statistical values of women participants' opinion for impact of their salaries on different factors of family presented in one sample T-test Table 6 are as follows:

1. Women participants opinion that their income nourished "financial position and status" shows significance $($ Sig. $=.000)$ with the positive $t$ value 4.264 which show the significant statistical difference between the sample estimated populations mean and the comparison population mean. Thus it can be concluded that financial position and status of family is majority affected factors of family by the income of women.

2. Women participants opinion that their income nourished "societal status and position" shows significance (Sig. $=.000$ ) with the positive t value 4.064 which reveals the significant statistical difference between the sample estimated populations mean and the comparison population mean. Thus it may be seen that societal status and position of family is majority affected factors of family by the income of women.

3. Women participants opinion that their income nourished "living standard and statue" shows significance (Sig. $=.000$ ) with the positive $\mathrm{t}$ value 21.903 which depicts the significant statistical difference between the sample estimated populations mean and the comparison population mean. Therefore it depicts that living standard and statue of family is majority affected factors of family by the income of women.

4. Women participants opinion that their income nourished "education of children" shows significance (Sig. = .003) with the positive $\mathrm{t}$ value 2.967 which show the significant statistical difference between the sample estimated populations mean and the comparison population mean. Thus it can be observed that education of children of family is majority affected factors of family by the income of women.

5. Women participants opinion that their income nourished "family and personal health security" shows significance $($ Sig. $=.047)$ with the positive $t$ value 1.996 which reveals the significant statistical difference between the sample estimated populations mean and the comparison population mean. Thus it has been found that family and personal health security is majority affected factors of family by the income of women.

6. Women participants opinion that their income nourished "social involvement" shows insignificance $($ Sig. $=.072)$ with the positive $t$ value 1.803 which depicts the insignificant difference between the sample estimated populations mean and the comparison population mean. Thus it can be concluded that social involvement of family is not affected factor of family by the income of women.

7. Women participants opinion that their income nourished "quality of life" shows significance (Sig. = .000 ) with the positive $t$ value 6.593 which show the significant statistical difference between the sample estimated populations mean and the comparison population mean. Thus it can be observed that quality of life of family is majority affected factors of family by the income of women.

8. Women participants opinion that their income nourished "risk taking capabilities" shows significance (Sig. $=.000$ ) with the positive $\mathrm{t}$ value 8.688 which reflects the significant statistical difference between the sample estimated populations mean and the comparison population mean. Thus it can be concluded that risk taking capabilities of family is majority affected factors of family by the income of women.

This relationship between the women participants' opinion for the income used in different heads of family and its overall impact on the different factors will help to examine the impact of working women income on overall development and nourishment of family of working women. As it reflect their economic contribution in the development of family. To examine the relationship Univariate test has been performed. 
Table 7: Univariate Test Table

\begin{tabular}{|c|c|c|c|c|c|}
\hline \multicolumn{6}{|l|}{ Tests of Between-Subjects Effects } \\
\hline \multicolumn{6}{|c|}{ Dependent Variable: Income of working women nourish their family status } \\
\hline Source & $\begin{array}{l}\text { Type III Sum of } \\
\text { Squares }\end{array}$ & Df & $\begin{array}{l}\text { Mean } \\
\text { Square }\end{array}$ & $\mathrm{F}$ & Sig. \\
\hline Corrected Model & $1252.206^{\mathrm{a}}$ & 8 & 156.526 & 14.270 & .000 \\
\hline Intercept & 5643.323 & 1 & 5643.323 & $\begin{array}{l}514.49 \\
0\end{array}$ & .000 \\
\hline $\begin{array}{l}\text { Score of Application of income in } \\
\text { family }\end{array}$ & 1252.206 & 8 & 156.526 & 14.270 & .000 \\
\hline Error & 4837.225 & 441 & 10.969 & & \\
\hline Total & 51772.000 & 450 & & & \\
\hline Corrected Total & 6089.431 & 449 & & & \\
\hline
\end{tabular}

\section{Source: Field Survey Year 2015}

Table 7 depicts that there is a significant (.000) relationship between the interaction of impact of working women income on overall development and nourishment of family of working women, the $\mathrm{F}$ value observed for the relationship is 14.270 and the $\mathrm{R}$ value which shows the association between the participating variables is .206. Thus hypothesis $\mathbf{H}_{\mathrm{a} 13}$ has been accepted which confirms that application of working women income in different heads of family nourishes their family statue.

Table 8: Status of Hypothesis established to examine relationship between the applications of women income in different heads of family nourishes family statue

\begin{tabular}{|l|l|l|}
\hline S. No. & Hypothesis & Status \\
\hline 1. & $\begin{array}{l}\mathbf{H}_{\text {a13 }}: \text { Application of working women income in different } \\
\text { heads of family nourishes their family statue. }\end{array}$ & Accepted \\
\hline
\end{tabular}

\section{Conclusion}

From the analysis of women participants' opinion for the factors of family which are nourished by their income it is observed that women participants are agreeing that their income is directly affecting the Financial Position and Status, Societal Status and Position, Living Standard and Statue, Education of Children, Family and Personal Health Security, Quality of life and Risk taking capabilities. Thus it could be concluded that income or salary of woman affecting all the possible factors of their family positively which shows their significant contribution in family economy. A significant relationship between the interaction of impact of working women income on overall development and nourishment of family of working women has been identified. Application of working women income in different heads of family nourishes their family statue as well.

\section{References}

1. Efroymson Debra, Biswas Buddhadeb, and Ruma Shakila (2007 September). The Economic Contribution of Women in Bangladesh Through their Unpaid Labor. Analysis and report writing, WBB Trust - HealthBridge Dhaka. 
2. Ekesionye E. N and Okolo A. N. (2012 January 5). Women empowerment and participation in economic activities: Indispensable tools for self-reliance and development of Nigerian society. Department of Educational Foundations, Faculty of Education, University of Nigeria, Nsukka, Nigeria. Educational Research and Review Vol. 7(1), pp. 10-18.

3. Gandhi Dheeraj and Sharma Vaibhav (2014 August). Women Entrepreneurship: The Emerging Economic Workforce In The 21st Century. IRACST - International Journal of Commerce, Business and Management (IJCBM), ISSN: 2319-2828 Vol. 3, No. 4.

4. Jehan Qamar (2000 Dec). Role of Women in Economic Development of Pakistan. Thesis submitted to the Pakistan study centre, University of Balochistan, Quetta.

5. Kausar Tasnim. Women's Contribution to the Family Budget: Informal Labor Market in Pakistan (A Case Study of Bahawalpur District). Thesis submitted at Department of Economics, The Islamia University of Bahawalpur.

6. Kumari Reena, Pandey Aviral. Women's Work Participation In Labour Market In Contemporary India.

7. Koko U. (1992). Empowering People for Health and Family Planning. IASSI Quarterly, Vol.11, p. 2.

8. Rahman R. I. and Islam R. (2013). Female labour force participation in Bangladesh: trends, drivers and barriers, ILO Asia-Pacific Working Paper Series (New Delhi, ILO) 